\title{
Meta-analysis of dry cow management for dairy cattle. Part 1. Protection against new intramammary infections
}

\author{
T. Halasa, ${ }^{* 1}$ O. Østerås, $†$ H. Hogeveen, ${ }^{*}$ T. van Werven, ${ }^{*}$ and M. Nielen* \\ *Department of Farm Animal Health and Reproduction, Utrecht University, PO Box 80151, 3584 CN Utrecht, the Netherlands \\ †Department of Production Animal Clinical Sciences, Norwegian School of Veterinary Science, PO Box 8146 Dep., N-0033 Oslo, Norway
}

ABSTRACT

The objective of this study was to estimate the preventive effect of various dry cow management measures against quarter new intramammary infections (IMI) during the dry period up to $21 \mathrm{~d}$ postcalving. Moreover, the potential publication bias was assessed in the studies selected for this analysis. The intervention measures were blanket dry cow therapy (BDCT), selective dry cow therapy (SDCT), cloxacillin compared with other dry cow therapy products, and teat sealant. A meta-analysis relative risk (RR) was calculated per intervention and pathogen group when enough studies were available from the 33 selected studies. Results of the meta-analyses were examined using publication bias tests. Blanket dry cow therapy showed significant protection against new IMI caused by Streptococcus spp. [the pooled RR was 0.39 (0.30 to 0.51$)$ ] but no protection was observed against coliform new IMI [the pooled RR was 0.95 (0.81 to 1.10)]. After correction for publication bias, it became doubtful whether DCT is protective against new Staphylococcus spp. IMI. Cloxacillin showed similar protection against new quarter IMI compared with other DCT products [the pooled RR was 1.09 (0.94 to 1.25)]. Selective dry cow therapy showed higher protection against new IMI compared with no DCT [the pooled RR was 0.51 (0.30 to 0.86)]. However, BDCT showed more protection when compared with SDCT [the pooled RR was 0.55 (0.37 to 0.80$)$ ], but the inference about whether BDCT is superior to SDCT was dependent on whether the selection criteria for SDCT was at the cow or quarter level. Internal teat sealants showed significant protection against new IMI during the dry period [the pooled RR was 0.39 (0.18 to $0.82)]$. Publication bias should be taken into account when attempts are made to review literature in a metaanalysis.

Key words: mastitis, dairy cattle, dry period, metaanalysis

Received September 23, 2008.

Accepted March 7, 2009.

${ }^{1}$ Corresponding author: t.h.halasa@uu.nl

\section{INTRODUCTION}

Although risk of new IMI for environmental pathogens is high in the early and late dry period (DP), the risk for the "contagious" pathogens, such Staphylococcus aureus and Streptococcus agalactiae, is lower in the DP than at other times (Bradley and Green, 2004). Different methods have been attempted to control new IMI during the DP. Several dry cow therapy (DCT) products were tested and compared with each other to optimize protection (Parkinson et al., 2000). Emerging antibiotic bacterial resistance, combined with economic incentives, led to selective DCT (SDCT) based on cow characteristics, such as SCC approaching dry off or clinical IMI history (Morris et al., 1978), or both.

An alternative to DCT is the use of an internal or external teat sealant (TS), which is meant to prevent pathogen access to the mammary glands (Meaney, 1976). Teat sealant application has been recommended by the National Mastitis Council, together with DCT in some cases to provide higher protection against new IMI (Godden et al., 2003).

The importance and the protective effect of DP management on new IMI are well recognized (Bradley and Green, 2004). However, large variations in the protective effect and the risk of new IMI can be encountered when comparing the different studies (Bradley and Green, 2004). Moreover, different interventions are expected to provide different degrees of protection. For calculations of the economic effects and subsequent support of decisions, it is essential to quantify an estimate of the risk of new IMI by using the different DP interventions. Only one study quantified summary risks of new IMI related to the DP intervention (Robert et al., 2006). However, this study focused only on quantifying the effect of DCT with and without teat sealants. The protective effect postcalving was not estimated, which might be important because some long-acting antibiotics are expected to limit new IMI around calving and early lactation (Pearson and Wright, 1969). More important, the potential publication bias in the studies reviewed was not assessed. Because studies that result in large and interesting treatment effects are more likely to be 
published than studies that show relatively small or no treatment effects, the outcome could be a biased body of research (Rothstein et al., 2005). Therefore, it is important to address and discuss this potential bias to draw proper conclusions on the preventive effect of DCT and other interventions. Meta-analysis is a statistical analysis of a large collection of analytical results from individual studies for the purpose of integrating the findings, which would facilitate drawing conclusions based on the available information (Dohoo et al., 2003). The technique is powerful in the sense that it considers study attributes, such as study precision, and weight those properly, but in some cases, the diversity among studies demands caution while drawing conclusions (Dohoo et al., 2003). The objectives of the present study were to 1) provide a summary quantification of the protective effect of different DP interventions on the risk of new IMI during the DP up to $21 \mathrm{~d}$ postcalving, based on meta-analysis of existing peer-reviewed literature, and 2) address and discuss the potential bias in the existing peer-reviewed literature.

\section{MATERIALS AND METHODS}

\section{Papers Selected for Analysis}

A search was conducted on literature related to the DP intervention published between 1930 and the beginning of 2008. The search was carried out using 2 methods: 1) search by key words in PubMed (the National Library of Medicine, Bethesda, MD, using the following key words in different combinations: dry period, transitional period, prepartum, peripartum, postpartum, new intramammary infection, mastitis, pathogen, cattle, cow, dairy, management, control, udder health, dry off, therapy, treatment), and 2) reference citation procedure in the ISI Web of Knowledge (Thompson Reuters Corporation, Philadelphia, PA), where a search was conducted for studies that cited older studies.

Papers included in the meta-analysis 1) had to be original research papers published in peer-reviewed journals; 2) had to report the number or the rate of new IMI at the quarter level in at least 2 groups (treated and control group) and the total number of quarters in each group; 3) could include only papers that had both pre-dry off and postcalving milk sampling at the quarter level, as by definition these were the only studies that could provide the new IMI data; and 4) had to report the outcome of a new data set or new protocol. When several studies were published based on the same data, the most detailed study was used. Further details of the studies are provided in subsequent sections.

A total of 33 studies fitted the above criteria for inclusion in the meta-analyses. When studies reported the outcome of one or several protocols, Roman numerals were added to distinguish protocols. Both negative control (i.e., those that included placebo or untreated cows or quarters) and positive control designs were included in the analyses.

Two formats for randomization and treatment were observed in the selected studies: 1) the whole udder was assigned to either the treatment or control group (between-cow comparison), or 2) one or more quarters of the udder were assigned to the treatment group and the other quarters were assigned to the control group (within-cow comparison).

Because different studies differed in design and in the observational units, discrepancies were expected that could influence the validity of the meta-analysis. Data related to the study design, level of analysis, and dry cow management were recorded from the original studies and are presented in Table 1, in Appendix Tables $\mathrm{A} 1, \mathrm{~A} 2$, and $\mathrm{A} 3$, and in the descriptive results.

\section{Management Groups Involved in the Meta-Analyses}

Blanket DCT (BDCT) was compared with no DCT, based on studies that reported the incidence or number of new quarter IMI during DP up to $21 \mathrm{~d}$ postcalving as a cumulative incidence. The $21 \mathrm{~d}$ postcalving was used as a cut-off value because most studies took milk samples up to $21 \mathrm{~d}$ postcalving. Moreover, studies that used longer intervals could actually be partly reflecting the effects of early lactation management, and hence tend to nullify any effects of DCT that presumably were not having effects that far from calving.

Studies that compared cloxacillin with other DCT products and that reported the number or incidence of new quarter IMI during the DP were included in the analysis. In those studies, sampling at a single time point just after calving was used to define the presence of a new IMI. Cloxacillin was included as the treatment group and the other DCT product was included as the control group. There was not enough data to conduct comparisons between other antibiotics; hence, only cloxacillin was used for comparison with other DCT products.

The SDCT comparison was based on studies that measured the rate or number of new quarter IMI in the SDCT compared with no DCT during DP up to $21 \mathrm{~d}$ postcalving as a cumulative incidence. The analysis was carried out separately for quarter- or cow-level treatment and was reported as a combined overall effect. A separate meta-analysis was carried out for studies that compared SDCT with BDCT as a positive control group.

Studies that investigated the protective effect of TS using negative or positive control groups were analyzed 
Table 1. Description of each study involved in the meta-analyses, in alphabetical order

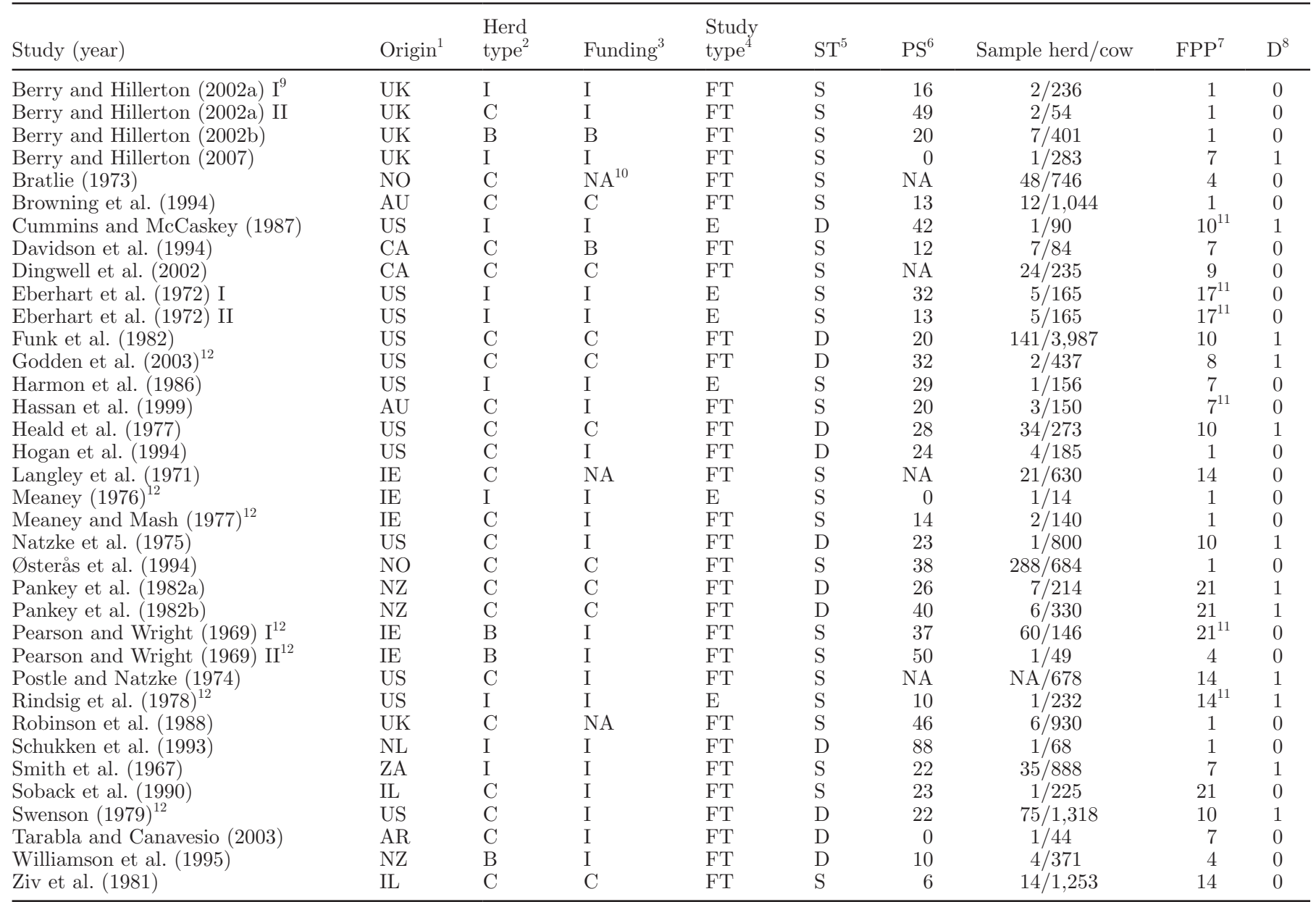

${ }^{1} \mathrm{UK}=$ United Kingdom; NO = Norway; $\mathrm{AU}=$ Australia, US = United States; $\mathrm{CA}=$ Canada; $\mathrm{IE}=\mathrm{Ireland} ; \mathrm{NZ}=\mathrm{New}$ Zealand; NL = the Netherlands; ZA = South Africa; AR = Argentina; IL = Israel.

${ }^{2}$ Type of herd where the study was conducted: institutional and research herds (I), commercial herds (C), or both herd types (B).

${ }^{3}$ Source of funding: institutional and governmental (I), commercial (C), or both (B).

${ }^{4}$ Study type: field trial (FT) or experiment (E).

${ }^{5}$ Samples type used to confirm diagnosis: single (S) or double (D).

${ }^{6}$ Prevalence $(\%)$ of IMI at dry off.

${ }^{7}$ Follow-up period postcalving in days.

${ }^{8}$ Definition of new IMI at calving or postcalving considered only new IMI from healthy quarters at dry off (0) or from all quarters at dry off (1).

${ }^{9}$ The Roman numerals represent protocols within a study.

${ }^{10}$ Not available.

${ }^{11}$ Collected extra postcalving sample.

${ }^{12}$ Within-cow comparison was conducted (format 1). The other studies included between-cow comparison (format 2).

together. The studies reported the number or incidence of new quarter IMI during DP up to $21 \mathrm{~d}$ postcalving as a cumulative incidence in the treatment and control groups.

A comparison was also conducted on supplementations that enhanced the immune system to better protect against new IMI during the DP. These supplementations were vitamins, minerals, and J5 vaccine. Another comparison was also conducted on teat dipping during the DP because it could protect cows from new
IMI during the DP. These 2 analyses were conducted to complete the message of the current study, in which all interventions that could protect against new IMI during the DP were reviewed in meta-analyses. The papers in these 2 analyses are not summarized or referred to, but the outcomes and the reasons that impeded complete presentation of results are discussed briefly.

Milk and Secretion Samples for Bacterial Culturing. In most studies, milk samples were collected at dry off, and at calving or within few days after calv- 
ing to diagnose IMI during the DP. Some studies collected 1 extra milk sample (up to $21 \mathrm{~d}$ after the calving sample) to examine the effects postcalving (Table 1). In 21 studies, 2 or more consecutive single samples were collected to diagnose IMI, while a duplicate sample was collected in the other studies (Table 1).

\section{Definition of a New Quarter IMI in the Meta-Analysis}

A quarter was considered as having a new IMI when a pathogen was isolated in the calving or postcalving samples from a quarter that was free of pathogen at the previous sampling or that had a different pathogen (or pathogens) in the dry-off sample. The majority of the studies defined a new IMI at calving or postcalving only when a pathogen was isolated from a previously healthy quarter (Table 1).

\section{Recalculating the Incidence of New Quarter IMI in the Meta-Analysis}

The majority of studies defined a new IMI in healthy quarters at dry off. Hence, the incidence of new quarter IMI was recalculated for all studies based on the number of healthy quarters at dry off being the number of quarters at risk for new IMI (Table A3).

\section{Meta-Analysis Procedure}

Outcome Parameters. The relative risk (RR) of new IMI was calculated as the incidence of new quarter IMI in the treatment group divided by the incidence of new quarter IMI in the control group per intervention and were pooled over studies in separate meta-analyses using a commercial analytical package (Comprehensive Meta-Analysis, 2008): The pooled RR was calculated per intervention as an overall effect (all pathogens together), and per pathogen group (Staphylococcus, Streptococcus, and coliforms) separately. In studies that included more than one protocol, a combined effect was calculated per study (Comprehensive Meta-Analysis, 2008). Because studies were conducted by different people, in different areas, and at different times, which create a heterogeneous population of studies, a random effect model was used to estimate the pooled RR. The pooled risk differences were similarly estimated. Forest plots were used to provide illustration of the calculated RR per study as well as the overall pooled effect of all studies in the last line of the plot. The forest plot is a graphical presentation of the results that displays the point estimate and confidence interval of the effect observed in each study, along with the summary estimate and its confidence interval (Dohoo et al., 2003).
Meta-Regression. A weighted meta-regression was conducted in an attempt to explain the variation among studies. Factors were selected for inclusion in the model based on expert assessment of likely factors, which were the factors presented in Table 1 (except sample size). Additionally, a factor gram was defined to discriminate between studies that isolated only gram-positive bacteria and studies that isolated gram-positive and gramnegative bacteria. All the above factors were regressed against the $\mathrm{RR}$ results of each study and weighted by the inverse variance (Dohoo et al., 2003).

The variables were first tested in univariable models and then combined in one multivariable model by using a backward stepwise regression method. A liberal $P<0.3$ was chosen for the variable to be included in a combined multivariable model. In cases of a significant association between the explanatory variable and the dependant variable (RR per study) with $P<$ 0.05 in the combined multivariable model, the variable was believed to explain the heterogeneity significantly. A meta-analysis was carried out only when at least 4 studies were available (Robert et al., 2006).

Publication Bias. The publication bias was assessed using funnel plots. A funnel plot is a plot of a measure of study size (standard error) on the vertical axis as a function of effect size on the horizontal axis. Large studies appear toward the top of the graph, and tend to cluster near the mean effect value. Smaller studies appear toward the bottom of the graph, and will be dispersed across a range of values. Methods included the fill and trim method of Duval and Tweedie (2000), the rank correlation test of Begg and Mazumdar (1994), and the regression test of Egger et al. (1997). When significant publication bias and change on the estimated pooled RR were detected, the number of studies necessary to reverse the overall pooled effect was calculated using the fail-safe $\mathrm{N}$ method of Orwin (1983). The study influence was also examined using the one study removed method (Dohoo et al., 2003). When significant publication bias was deemed to exist, the pooled RR was presented based on the fill and trim method (Duval and Tweedie, 2000) estimation after correcting for the bias. The interpretation of each of the above-mentioned tests is provided in the Results and the Discussion sections. It is important to mention that these methods are hypothetical and based on statistical theory. They do not necessarily prove existence of bias, but they do indicate the potential to bias existence based on a statistical technique that mainly relate the effect size to the study size (Thornton and Lee, 2000). Further information about the strong and weak points of the publication bias methods are mentioned in the Discussion section and are discussed in detail by Thornton and Lee (2000). 


\section{RESULTS}

\section{Descriptive Results}

Herds, Cows, and Funds. Eight studies had been conducted in institutional or research herds, 21 in commercial herds, and 4 in both research and commercial herds (Table 1). Funding of 19 studies had been obtained from institutional and governmental funds, 9 from commercial funds, and 2 from both institutional and commercial company funds, and the source of funding was unknown in 3 studies (Table 1). The number of herds varied from 1 herd, mainly in experimental studies, to 141 herds in field trials, the number of cows per study varied from 14 cows (also in an experiment) to 3,987 in field trials (Table 1 ).

Management of Dry and Lactating Cows. In nearly all studies, dry cows were separated from lactating cows. In some studies, dry cows were kept in separate stalls from a few days before calving until calving or for a few days postcalving and then moved to the dairy herd. Generally, dry cows were housed on pasture, in free stalls, or in closed barns, and lactating cows were housed in free stalls or on pasture. The bedding mentioned was frequently sand, sawdust, or straw.

Experimental Design. All studies involved in this analysis were randomized field trials (28 studies) or experiments ( 5 studies; Table 1). Although the inclusion criteria varied among studies, the infection status at dry off was frequently used to include or exclude cows (Table A1). The majority of the studies had a negative control group, but some had positive controls (Table A2), and the majority of studies applied a between-cow comparison.

Bacteriological Culturing Procedure. The procedure of the National Mastitis Council was followed in most studies (Hogan et al., 1999). Other studies used modified procedures based on this source. Nevertheless, in all studies, sample handling from the farm until processing was similar, especially storage, freezing, and processing of the samples. Milk samples were obtained by proper cleaning of the teat and after discarding the first 3 to 4 squirts of milk. In most studies, samples were stored at $-20^{\circ} \mathrm{C}$ until processed.

\section{Intervention}

$B D C T$ vs. No DCT ( $n=18$ Studies). The treatment was based on intramammary infusion of the antibiotic being tested in all quarters and all studies except 2 (Soback et al., 1990; Tarabla and Canavesio, 2003), in which systemic DCT was applied intramuscularly.

Cloxacillin vs. Other DCT Product $(n=$ 5 Studies). In the studies involved in the analysis, cloxacillin and the other product were applied by the intramammary route.

SDCT vs. No DCT and SDCT vs. BDCT $(n=$ 5 Studies in Each). Treatment was carried out in the SDCT group based on the unit of selection. Cow-level selection treatment resulted in treating all quarters of the whole udder. At the quarter level, only quarters that had elevated SCC or IMI were treated. Other quarters within the same udder were left untreated. When the control group was no DCT, no antibiotic was infused (negative control), but when BDCT was the control group (positive control), all quarters of the udder were infused with the same antibiotic that was used in the SDCT group at the quarter level only.

$T S$ vs. No TS and TS + BDCT vs. BDCT (n $=4$ Studies). Studies used internal TS, which was applied after proper hygiene of the teat and after DCT in the case of positive control group studies.

\section{Meta-Analysis Results}

$B D C T$ vs. No $\boldsymbol{D C T}$. In the separate univariable models, gram (gram positive vs. gram positive and negative), year of publication (because of suspicions of bacterial antibiotic resistance over time), and the continent where the study originated were selected to be included in the multivariable model $(P<0.3)$. None of the variables found to be associated at the univariate level was found to be associated in the final (multivariable) model.

Overall, BDCT was protective against new IMI compared with untreated controls (Table 2). However, the protection varied among pathogens (Table 2). When Staphylococcus spp. were involved, and before adjusting for publication bias, DCT quarters had 0.62 (0.47 to $0.83)$ times less risk of new IMI than untreated quarters. Applying the one study removed method showed that removing any of the studies did not alter the random pooled RR significantly (Figure 1). The Begg and Mazumdar rank correlation test suggested that there was no correlation between the study size and effect $(P=0.33)$. However, the regression test of Egger et al. contradicted the Begg and Mazumdar rank correlation test, suggesting a significant association between study size and effect size (intercept $=-1.73$ with 16 df, one-tailed $P=0.01$ ). The fill and trim method of Duval and Tweedie indicated no missing studies on the left-hand side of the funnel plot, but 7 studies (black spots) were missing on the right-hand side to reach complete symmetry (Figure 2). This figure indicates that if publication bias did not exist and complete symmetry was reached by including the missing studies, the preventive effect would shift to the null effect. Because significant publication bias was indicated (Figure 2), 
the number of studies necessary to move the pooled $\mathrm{RR}$ above 1 was calculated using fail-safe $\mathrm{N}$ method of Orwin. According to the Orwin fail-safe N method, and when the mean $\mathrm{RR}$ in the missing studies was assumed to be 1.10 , the number of necessary studies was 17 , but when the mean RR in the missing studies was assumed to be 1.20 , the number of necessary studies was only 8 . This number of studies is quite low, suggesting that the protective effect of DCT against new Staphylococcus spp. IMI during the DP up to $21 \mathrm{~d}$ postcalving might be truly insignificant.

When meta-analysis was carried out for the Streptococcus spp. group, DCT provided high protection against Streptococcus spp. (Table 2). All publication bias tests indicated an absence of significant potential bias. The protection of DCT against coliforms was insignificant (Table 2). All publication bias tests indicated an absence of potential bias.

Cloxacillin vs. Other DCT Products. In general, other DCT showed similar protective effects from new IMI during DP compared with cloxacillin (Table 2 ). Removing one study altered the effect, which is expected when a small number of studies are used (results not shown). The Duval and Tweedie fill and trim method suggested that 2 studies were missing from the right-hand side, which would support the finding that cloxacillin provides similar protection compared with other DCT (results not shown). The regression test of Egger et al. supported the presence of publication bias $(P=0.01)$. Correcting for publication bias would only confirm the nonsignificant difference between cloxacillin and other DCT in protection against new IMI during the DP.

There was no significant difference between cloxacillin and other DCT against new Staphylococcus spp. quarter IMI (Table 2). All publication bias tests indicated an absence of significant publication bias. The analysis was not carried out for other pathogen groups because the number of studies available was less than 4 .

$S D C T$ vs. No DCT or SDCT vs. BDCT. Selective DCT provided significant protection against new quarter IMI, and protection was slightly higher when selection and treatment were carried out at the cow level (Figure 3). When SDCT was compared with BDCT, BDCT showed higher protection than SDCT (Figure 4). Nonetheless, there was no significant difference in protection from new quarter IMI between SDCT and BDCT when the selection unit was the cow, with the whole udder treated (Figure 4). When the $\mathrm{SDCT}$ selection unit was the quarter, BDCT provided better protection from new quarter IMI (on a population level) than SDCT (Figure 4).

In both SDCT comparison analyses, the one study removed test showed that some studies had a significant influence on the pooled RR, which is expected when a small number of studies are available (results not shown). Because of the limited number of studies, the potential publication bias in relation to grouping was not checked further. Analysis was also not conducted per pathogen group because of the limited number of studies.

TS vs. No TS or TS +BDCT vs. BDCT. The only study with the positive control group gave similar protection compared with the other studies $(P>0.05)$; therefore, a combined RR based on all studies is presented. In general, TS-injected quarters had 0.39 (0.18 to 0.82 ) times less risk of new IMI than non-TS-injected quarters (Table 2). None of the publication bias tests indicated the existence of bias (results not shown). Analysis was not conducted per pathogen group because of the limited number of studies.

\section{DISCUSSION}

To limit the effect of prevalence at dry off on the incidence of new IMI during the DP and postcalving, and because it is the clearest indication of new IMI, the incidence of new IMI in the treatment and control groups was calculated by considering only the number of healthy quarters at dry off to be the number of quarters at risk. Because infected quarters at the start of the DP might recover and become infected again during the DP (reinfection), recalculation of the incidence might have estimated the true incidence wrongly in both groups. However, because all studies involved were randomized, the RR would not be affected because recalculation of the incidence was similar for the treatment and control groups within studies. In contrast, the pooled risk difference might have been slightly overestimated, but the results of the risk difference showed the same patterns of $\mathrm{RR}$ results. Risk difference results are not presented owing to space restrictions, but are available from the first author. The calculated incidence assumed the uninfected glands at dry off to be the only quarters at risk. This might restrict the generalization of DCT efficacy on a population level, because infected glands might recover and also contract new IMI during the DP. However, because the majority of studies involved healthy quarters at dry off as quarters to be at risk of new IMI, the analysis was conducted accordingly. Thus, conclusions of the current meta-analysis should be interpreted carefully. The companion paper provides a comprehensive discussion about the efficacy of DCT during the DP based on the current study and the companion study (Halasa et al., 2009).

Dry cow therapy was the largest group of studies, but results were heterogeneous, indicating unexplained risk factors for the efficacy of DCT and that perhaps a pro- 
Table 2. Pooled relative risk (RR) together with the $95 \%$ confidence interval as estimated based on the corresponding studies in the meta-analysis for the different dry cow interventions for all pathogens (overall) and per pathogen group ${ }^{1}$

\begin{tabular}{|c|c|c|}
\hline Intervention and pathogen group & Studies included in each meta-analysis to estimate the pooled $R R$ & $\begin{array}{c}\text { Pooled } \mathrm{RR}^{2}(95 \% \\
\text { confidence interval) }\end{array}$ \\
\hline \multicolumn{3}{|l|}{ BDCT vs. no DCT } \\
\hline Overall & $\begin{array}{l}\text { Cummins and McCaskey (1987); Dingwell et al. (2002); Eberhart and Buckalew (1972); Funk et al. (1982); } \\
\text { Harmon et al. (1986); Hassan et al. (1999); Heald et al. (1977); Hogan et al. (1994); Langley et al. (1971); } \\
\text { Natzke, et al. (1975); Pankey et al. (1982a,b); Pearson and Wright (1969); Postle and Natzke (1974); } \\
\text { Schukken et al. (1993); Smith et al. (1967); Soback et al. (1990); Swenson (1979); } \\
\text { Tarabla and Canavesio (2003); Williamson et al. (1995) }\end{array}$ & $0.61(0.53$ to 0.71$)$ \\
\hline Staphylococcus spp. & $\begin{array}{l}\text { Cummins and McCaskey (1987); Eberhart and Buckalew (1972); Funk et al. (1982); Harmon (1986); } \\
\text { Hassan et al. (1999); Heald et al. (1977); Hogan et al. (1994); Langley et al. (1971); Pankey et al. (1982a,b); } \\
\text { Pearson and Wright (1969); Postle and Natzke (1974); Schukken et al. (1993); Smith et al. (1967); } \\
\text { Soback et al. (1990); Swenson (1979); Tarabla and Canavesio (2003); Williamson et al. (1995) }\end{array}$ & $0.76^{3}(0.54$ to 1.07$)$ \\
\hline Streptococcus spp. & $\begin{array}{l}\text { Cummins and McCaskey (1987); Eberhart and Buckalew (1972); Funk et al. (1982); Harmon et al. (1986); } \\
\text { Hassan et al. (1999); Heald et al. (1977); Hogan et al. (1994); Pankey et al. (1982a,b); Pearson and Wright (1969); } \\
\text { Postle and Natzke (1974); Smith et al. (1967); Swenson (1979); Tarabla and Canavesio (2003) }\end{array}$ & $0.39(0.30$ to 0.51$)$ \\
\hline Coliform & $\begin{array}{l}\text { Cummins and McCaskey (1987); Eberhart and Buckalew (1972); Funk et al. (1982); Harmon et al. (1986); } \\
\text { Hassan et al. (1999); Hogan et al. (1994); Postle and Natzke (1974) }\end{array}$ & $0.95(0.81$ to 1.10$)$ \\
\hline
\end{tabular}

Clox vs. other DCT

Overall

Staphylococcus

SDCT vs, no DCT

SDCT vs. BDCT

TS vs. no TS or TS + DCT vs. DCT

Overall Berry and Hillerton (2002b); Berry and Hillerton (2007); Godden et al. (2003); Meaney (1976)

Davidson et al. (1994); Funk et al. (1982); Langley et al. (1971); Meaney et al. (1977); Ziv et al. (1981)

Davidson et al. (1994); Funk et al. (1982); Langley et al. (1971); Ziv et al. (1981)
Berry and Hillerton (2002a); Bratlie (1973); Hassan et al. (1999); Østerås et al. (1994); Williamson et al. (1995)

Berry and Hillerton (2002a); Bratlie (1973); Hassan et al. (1999); Østerås et al. (1994); Williamson et al. (1995)
Browning et al. (1994); Hassan et al. (1999); Rindsig et al. (1978); Robinson et al. (1988); Williamson et al. (1995)

$1.09(0.94$ to 1.25$)$

$1.12(0.98$ to 1.27$)$

$1.83(1.24$ to 2.71$)$

$0.39(0.18$ to 0.82$)$

${ }^{1}$ Interventions were as follows: blanket dry cow therapy (BDCT), cloxacillin (Clox) vs. other dry cow therapy (DCT) products, selective DCT (SDCT), and teat sealant (TS). Footnotes are added to discriminate values presented after adjustment to publication bias when it significantly existed.

${ }^{2}$ Incidence of new quarter IMI in treated group divided by the incidence of new quarter IMI in the control group. RR $<1$, reduced risk of IMI; RR $=1$, no protection; RR $>1$, increased risk of IMI

${ }^{3}$ The pooled RR and the $95 \%$ confidence interval are presented based on the fill and trim method of Duval and Tweedie (2000) owing to the existence of significant publication bias. 


\begin{tabular}{|c|c|c|c|}
\hline \multirow[t]{2}{*}{ Study } & \multicolumn{3}{|c|}{ Statistics with study removec } \\
\hline & $\begin{array}{l}\text { Pooled } \\
\text { RR }\end{array}$ & $\begin{array}{c}\text { Lower } \\
\text { limit }\end{array}$ & $\begin{array}{c}\text { Upper } \\
\text { limit }\end{array}$ \\
\hline Cummins (1987) & 0.645 & 0.479 & 0.868 \\
\hline Eberhart (1972) & 0.653 & 0.490 & 0.870 \\
\hline Funk (1982) & 0.571 & 0.400 & 0.813 \\
\hline Harmon (1986) & 0.606 & 0.444 & 0.828 \\
\hline Hassan (1999) & 0.627 & 0.468 & 0.839 \\
\hline Heald (1977) & 0.598 & 0.442 & 0.808 \\
\hline Hogan (1994) & 0.627 & 0.466 & 0.844 \\
\hline Langley (1971) & 0.624 & 0.464 & 0.841 \\
\hline Pankey (1982a) & 0.632 & 0.466 & 0.857 \\
\hline Pankey (1982b) & 0.651 & 0.487 & 0.871 \\
\hline Pearson (1969) & 0.603 & 0.442 & 0.822 \\
\hline Postle (1974) & 0.612 & 0.451 & 0.831 \\
\hline Schukken (1993) & 0.620 & 0.462 & 0.831 \\
\hline Smith (1967) & 0.764 & 0.616 & 0.948 \\
\hline Soback $(1990)$ & 0.596 & 0.430 & 0.826 \\
\hline Swanson (1979) & 0.570 & 0.414 & 0.785 \\
\hline Tarabla (2003) & 0.630 & 0.471 & 0.843 \\
\hline Williamson (1995) & 0.615 & 0.457 & 0.827 \\
\hline Pooled RR & 0.624 & 0.467 & 0.834 \\
\hline
\end{tabular}

\section{Pooled RR (95\% CI)} with study removed

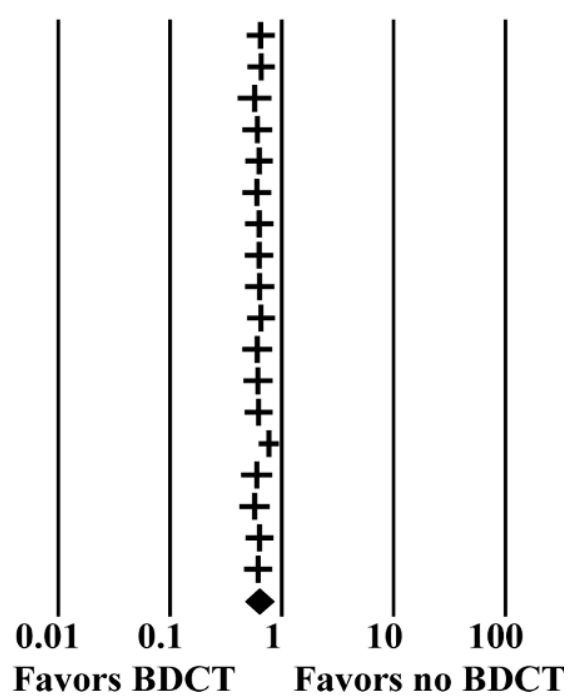

Figure 1. Forest plot of the change in the pooled relative risk (RR) of new quarter Staphylococcus spp. IMI during the dry period up to 21 d postcalving $[\mathrm{RR}=$ incidence of new quarter Staphylococcus spp. IMI in the blanket dry cow therapy (BDCT) group divided by the incidence in the untreated control group] together with the $95 \%$ confidence interval (CI), when the corresponding study was removed.

duction system-dependent decision about the efficacy of DCT may be important to consider. Several attempts were made to restrict the heterogeneity. Inclusion only of studies with a negative control group, or only of studies that reported new quarter IMI, or only of studies conducted on dairy cows (excluding primiparous and beef cattle), or only randomized studies did not improve the homogeneity. Including only peer-reviewed papers in the English language could have been a source of heterogeneity. Language might be a source of bias, because non-English-speaking researchers might publish their positive results in English-language journals to gain more publicity, whereas they might publish their negative results in their native language (Gregoire et al., 1995). Although attempts were made to use metaregression with several potential variables to explain the heterogeneity, none of them was able to explain it significantly. A possible source of heterogeneity could be the length of the DP such that the longer the DP, the higher the chance of new IMI because of the lower concentration of antibiotics around calving (Rindsig et al., 1978). However, because this information was not available in most studies, and because the length of the DP could differ considerably among cows within a study, it was not possible to test the effect of length of the DP on heterogeneity in the meta-regression.

The protective effect of DCT against new coliform IMI was not significantly higher than for untreated quarters (Table 2). Publication bias did not influence this result. In a previous meta-analysis (Robert et al., 2006), DCT also did not significantly protect cows from new coliform IMI during the DP. This was explained by the fact that new coliform IMI occurs late in the DP, when DCT might not provide protection against new IMI any longer because of the low concentration

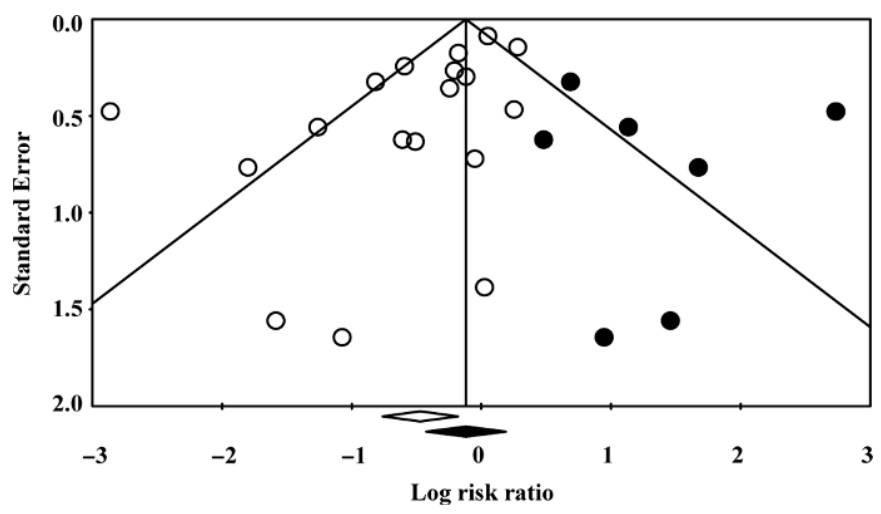

Figure 2. Funnel plot of the pooled relative risk (RR) of studies (empty circles) involved in the protective effect of dry cow therapy against new quarter Staphylococcus spp. IMI during the dry period up to $21 \mathrm{~d}$ postcalving $[\mathrm{RR}=$ incidence of new quarter Staphylococcus spp. IMI in the blanket dry cow therapy (BDCT) group divided by the incidence in the untreated control group]. The dark spots are the potential missing studies according to the fill and trim method of Duval and Tweedie (2000). [If they had existed, the pooled RR would have changed toward the null effect (the black diamond under the null effect)]. The open diamonds represent log pooled $\mathrm{RR}$ with confidence interval before correction of publication bias. The light circles are the 18 studies involved. 


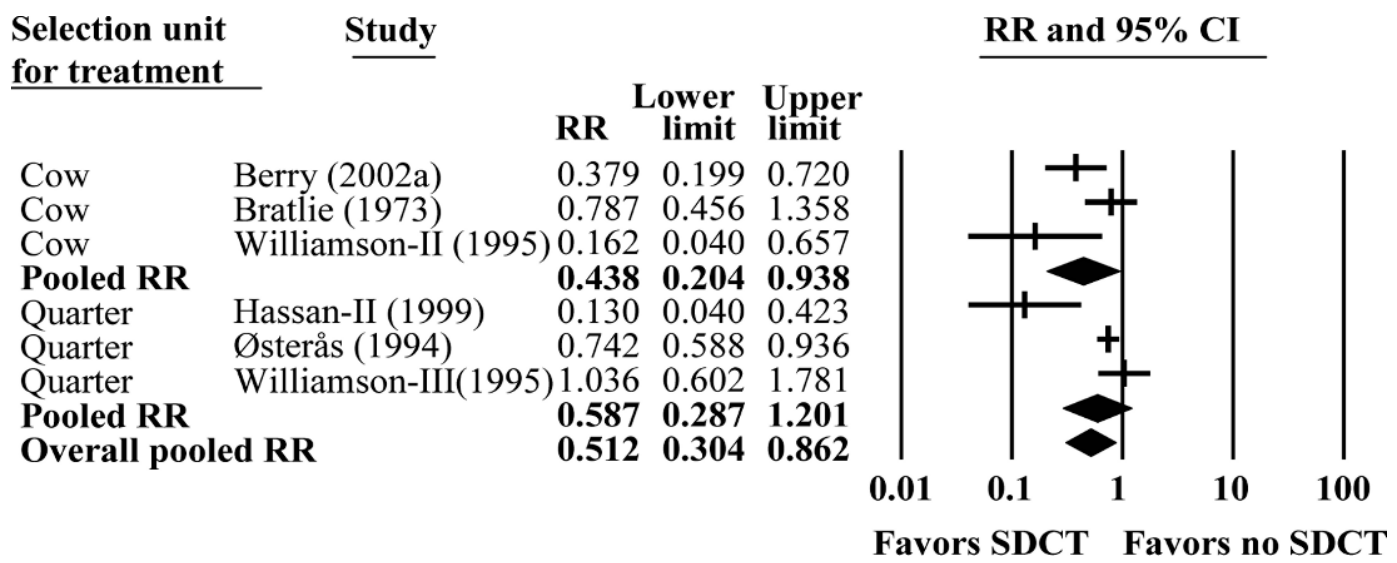

Figure 3. Forest plot of the relative risk $(\mathrm{RR})$ of new quarter IMI during the dry period up to $21 \mathrm{~d}$ postcalving $[\mathrm{RR}=$ incidence of new quarter IMI in the selective dry cow therapy (SDCT) group divided by the incidence in the untreated control group] per study, and the pooled RR per SDCT selection unit and as an overall pooled RR effect together with the $95 \%$ confidence interval (CI) in the 5 studies involved.

(Robert et al., 2006). Another explanation of the apparent lack of efficacy is that the spectrum of activity of many of the DCT products did not cover gram-negative pathogens (Bradley and Green, 2001).

On the basis of a random effect model, initially BDCT provided significant protection against new quarter Staphylococcus spp. IMI. However, publication bias tests indicated the presence of significant bias. Adding 7 studies to the right-hand side of the funnel plot (Figure 2), led to nullifying the effect and suggested that DCT does not protect significantly against new Staphylococcus spp. IMI. Although large and small studies are present on both sides of the plot, 3 large studies, including the largest study, suggested that DCT does not protect against new Staphylococcus spp. IMI (Figure 2). The fact that the inclusion criterion of many studies that showed significant protection against new Staphylococcus spp. IMI was not mentioned (Table A1) suggested a possible lower quality study design in those studies. Moreover, the 7 missing studies might have been conducted but not published in peer-reviewed journals because they showed no protective effect. The fact that 2 of these studies were small and another 2 studies relatively small (Figure 2) would support this speculation regarding why they were not published (Dohoo et al., 2003). The reason for not publishing the data could be that those studies were sponsored by commercial companies and that it would not be commercially beneficial to publish such data (Thornton and Lee, 2000). Another reason could be that the results might not have been interesting enough for publication. Many peer-reviewed journals do not publish results if they are not striking or interesting enough or if they fail to show significant differences between treatment effects (Ferguson, 2007). Moreover, researchers themselves might not attempt to publish their research when the results contradict previous expectations (Ferguson, 2007). The regression test of Egger et al. (1997) was

\begin{tabular}{ll}
$\begin{array}{l}\text { Selection unit } \\
\text { for treatment }\end{array}$ & Study \\
\cline { 1 - 2 } Cow & Browning-I (1994) \\
Cow & Rindsig-II (1978) \\
Cow & Williamson-II (1995) \\
Pooled RR & \\
Quarter & Hassan-III (1999) \\
Quarter & Browning-II (1994) \\
Quarter & Williamson-III (1995) \\
Quarter & Robinson (1988) \\
Pooled RR & \\
Overall pooled RR
\end{tabular}

\section{RR Lower Upper}

$\begin{array}{lll}1.505 & 1.048 & 2.161\end{array}$

$\begin{array}{lll}0.217 & 0.119 & 0.394\end{array}$

$\begin{array}{lll}0.386 & 0.092 & 1.612\end{array}$

$\begin{array}{lll}\mathbf{0 . 5 1 9} & \mathbf{0 . 1 1 7} & \mathbf{2 . 3 0 8}\end{array}$

$\begin{array}{lll}0.331 & 0.094 & 1.161\end{array}$

$\begin{array}{lll}2.445 & 1.753 & 3.410\end{array}$

$2.465 \quad 1.328 \quad 4.573$

$2.259 \quad 1.766 \quad 2.888$

$\begin{array}{lll}2.010 & 1.339 & \mathbf{3 . 0 1 7}\end{array}$

\begin{tabular}{lll}
$\mathbf{2} .010$ & 1.339 & 3.017 \\
\hline
\end{tabular}

\section{RR and $95 \%$ CI}

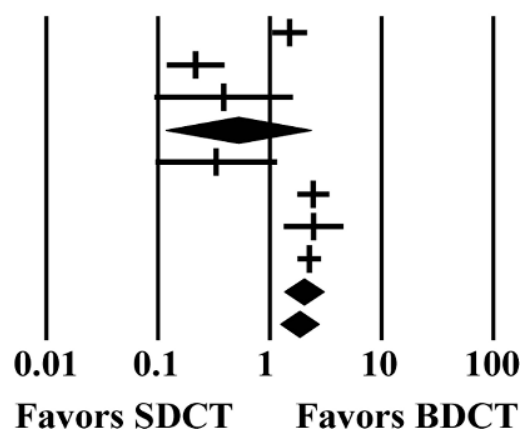

Figure 4. Forest plot of the relative risk (RR) of new quarter IMI during the dry period up to $21 \mathrm{~d}$ postcalving [RR $=$ incidence of new quarter IMI in the selective dry cow therapy (SDCT) group divided by the incidence in the blanket dry cow therapy (BDCT) group] per study, and the pooled RR per SDCT selection unit and as an overall pooled RR together with the $95 \%$ confidence interval (CI) in the 5 studies involved. 
reported to be powerful in detecting publication bias for heterogeneous data such as ours (Peters et al., 2006). The fail-safe N method of Orwin (1983) showed that adding a few studies would completely reverse the pooled $\mathrm{RR}$ and move it above 1 . The disadvantage of the fail-safe $\mathrm{N}$ method is that it calculates the number of studies that are necessary to alter the effect, but does not calculate the number of studies that are needed to reach a null effect, as indicated by Rothstein (2008). Therefore, in this case, fewer studies are expected to make the difference insignificant, depending on the average RR in those studies.

In a previous meta-analysis (Robert et al., 2006), DCT quarters had an RR of 0.75 (0.61 to 0.91 ) for new coagulase-positive Staphylococcus spp. IMI during the DP, but DCT quarters did not have significantly less risk in the case of coagulase-negative Staphylococcus. However, the potential publication bias was not investigated further in that study. A separate analysis for coagulase-positive Staphylococcus in the current study showed the same trends as for the Staphylococcus group as a whole, indicating that asymmetry existed because of the missing studies (results not shown). Moreover, because subtherapeutic doses were tested in 4 studies (Table A2), which might have affected the symmetry around the pooled RR, a separate subset was analyzed by removing protocols with subtherapeutic doses. Nevertheless, the fill and trim method of Duval and Tweedie (2000) suggested adding 5 studies, mainly small studies, to the right-hand side of the plot to reach complete symmetry, which would lead to nullifying the protective effect against new Staphylococcus spp. IMI during the DP up to $21 \mathrm{~d}$ postcalving (results not shown).

The procedure followed in the meta-analysis of Robert et al. (2006) to calculate the pooled RR apparently assumed one true pooled RR (fixed effect model). Because of the heterogeneous nature of the studies selected, this assumption was violated. Therefore, the pooled $\mathrm{RR}$ should have been calculated by assuming a distribution of true RR (random effect model), in which weighting would be applied differently, as indicated by Borenstein et al. (2007) and as applied in recent research (Duffield et al., 2008). Because different assumptions are involved for the different models of calculating the pooled $\mathrm{RR}$, the pooled $\mathrm{RR}$ would not be precise, and in some cases, it might actually fall out of the confidence limit of the true pooled RR (Borenstein et al., 2007). In the current study, the nature of the studies selected was taken into account and proper models and assumptions were considered.

Several studies found that many new Staphylococcus spp. IMI occur late in the DP and in early lactation (Soback et al., 1990; Hassan et al., 1999). Soback et al. (1990) indicated that the failure of DCT to prevent new
Staph. aureus IMI during the DP could have occurred because of the failure of the DCT to cure existing infections at dry off. Hogan et al. (1994) showed that DCT was not successful in preventing new Staph. aureus IMI during the DP. They suggested that because Staph. aureus is part of the normal flora of the teat skin, in the late DP, the teat canal would open and the bacteria would have access, causing new IMI. Rindsig et al. (1978) observed that the longer the DP, the greater the chance of new Staphylococcus spp. IMI, and reasoned that the decreased DCT concentration provided a less prophylactic effect. Analysis of data from a recent large field trial in Norway indicated that neither SDCT nor BDCT protected cows significantly from new quarter Staph. aureus IMI during the DP and early lactation (A. C. Whist, TINE Norwegian Dairies, Norwegian Cattle Health Services, Ås, Norway; unpublished data). When the publication bias tests indicate a potential bias, it might not ultimately be true. However, the methods are useful, because they indicate a potential bias, and hence enhance thinking of possible explanations that should be based on rational and biological reasoning. In our case and for all the rational and biological explanations mentioned above, it was deemed that publication bias could truly have existed in the peer-reviewed literature, hence making it difficult to conclude on the protective effect of BDCT against new quarter Staphylococcus spp. IMI during the DP up to $21 \mathrm{~d}$ postcalving. On the other hand, the pooled $\mathrm{RR}$ was $<1$, which economically might be good enough to pay off the cost of DCT, but economic analysis has still to be conducted.

The preventive effect of SDCT was significantly higher than not treating quarters (Table 2). When SDCT was compared with BDCT, and when selection was carried out at the cow level for SDCT, there was no significant difference between SDCT and BDCT. However, BDCT showed higher protection when SDCT selection was carried out at the quarter level (Figure 4). This might be explained because an infected quarter in a cow could have a higher chance of infecting other healthy quarters in the same cow during the DP than infecting healthy quarters in other cows in the DP (Buddle et al., 1987). Treatment at the cow level could or could not cure this infected quarter, but at least would prevent the infection of other healthy quarters. Another possible reason is a misclassification error, whereby some glands within a cow are incorrectly left untreated, for example, because of intermittent shedding of bacteria. Nonetheless, the small number of studies per stratum precluded meta-analysis per stratum; therefore, the results are presented as a stratified overall effect.

Generally, internal TS provided significant protection against new IMI (Table 2). Although large studies do exist, only 4 studies were found to fit our criteria. 
Therefore, more studies could be necessary to draw conclusions properly on the efficacy of TS.

A meta-analysis was conducted on studies that challenged the effect of external supplementation to enhance the immune system to protect against new IMI during the DP. The supplementations did not provide significant protection against new IMI during the DP. Similarly, teat dipping did not provide protection against new IMI during the DP. The number of studies per comparison was low and the diversity among studies was high, which precluded proper comparison and hence conclusions on the protective effect of these interventions against new IMI during the DP.

\section{CONCLUSIONS}

Dry cow therapy provided significant protection from new quarter IMI caused by Streptococcus spp. during the DP up to $21 \mathrm{~d}$ postcalving. No protection was indicated against new quarter coliform IMI. After correction for publication bias, it became doubtful whether DCT is protective against new quarter Staphylococcus spp. IMI. Cloxacillin provided similar protection against all new quarter IMI and was similarly effective against new quarter Staphylococcus spp. IMI compared with other DCT. Selective DCT provided significant protection against new quarter IMI when compared with no treatment. Selective DCT provided less protection when compared with BDCT, with quarter SDCT as the least effective. Teat sealants provided significant protection against new quarter IMI. Because results were shown to change drastically through the effect of publication bias, publication bias should be included whenever attempts are made to review literature in a meta-analysis.

\section{ACKNOWLEDGMENTS}

The authors acknowledge the help of Scott McDougall for providing some hard-to-find papers. This study is part of the 5-yr program of the Dutch Udder Health Centre and was financially supported by the Dutch Dairy Board (Zoetermeer, the Netherlands).

\section{REFERENCES}

Begg, C. B., and M. Mazumdar. 1994. Operating characteristics of a rank correlation test for publication bias. Biometrics 50:10881101.

Berry, E. A., and J. E. Hillerton. 2002a. The effect of selective dry cow treatment on new intramammary infections. J. Dairy Sci. 85:112-121.

Berry, E. A., and J. E. Hillerton. 2002b. The effect of an intramammary teat seal on new intramammary infections. J. Dairy Sci. 85:25122520 .
Berry, E. A., and J. E. Hillerton. 2007. Effect of an intramammary teat seal and dry cow antibiotic in relation to dry period length on postpartum mastitis. J. Dairy Sci. 90:760-765.

Borenstein, M., L. Hedges, and H. Rothstein. 2007. Meta-Analysis: Fixed Effect vs. Random Effects. Biostat Institute Inc., Englewood Cliffs, NJ.

Bradley, A. J., and M. Green. 2001. An investigation of the impact of intramammary antibiotic dry cow therapy on clinical coliform mastitis. J. Dairy Sci. 84:1632-1639.

Bradley, A. J., and M. Green. 2004. The importance of the lactating period in the epidemiology of intramammary infection and strategies for prevention. Vet. Clin. North Am. Food Anim. Pract. 20:547-568.

Bratlie, O. 1973. Dry cow therapy. Vet. Rec. 93:430-431.

Browning, J. W., G. A. Mein, P. Brightling, T. J. Nicholls, and M. Barton. 1994. Strategies for mastitis control: Dry cow therapy and culling. Aust. Vet. J. 71:179-183.

Buddle, B. M., M. Herceg, M. J. Ralston, and H. D. Pulford. 1987. Reinfection of bovine mammary glands following dry cow antibiotic therapy. Vet. Microbiol. 15:191-199.

Comprehensive Meta-Analysis. 2008. Meta-Analysis Manual. Biostat Institute Inc., Englewood, NJ.

Cummins, K. A., and T. A. McCaskey. 1987. Multiple infusions of cloxacillin for treatment of mastitis during the dry period. J. Dairy Sci. 70:2658-2665.

Davidson, T. J., I. R. Dohoo, and A. W. Donald. 1994. Comparing two dry cow treatments on the new infection and elimination rates of coagulase-negative staphylococci. Can. Vet. J. 35:775-776.

Dingwell, R. T., T. F. Duffield, K. E. Leslie, G. P. Keefe, L. DesCoteaux, D. F. Kelton, K. D. Lissemore, Y. H. Schukken, P. Dick, and R. Bagg. 2002. The efficacy of intramammary tilmicosin at drying-off, and other risk factors for the prevention of new intramammary infections during the dry period. J. Dairy Sci. 85:3250-3259.

Dohoo, I. R., S. W. Martin, and H. Stryhn. 2003. Veterinary Epidemiological Research. Atlantic Veterinary College Inc., Charlottetown, Prince Edward Island, Canada.

Duffield, T. F., A. R. Rabiee, and I. J. Lean. 2008. A meta-analysis of the impact of monensin in lactating dairy cattle. Part 2. Production effects. J. Dairy Sci. 91:1334-1346.

Duval, S., and R. Tweedie. 2000. A non-parametric "trim and fill" method of accounting for publication bias in meta-analysis. J. Am. Stat. Assoc. 95:89-98.

Eberhart, R. J., and J. M. Buckalew. 1972. Evaluation of a hygiene and dry period therapy program for mastitis control. J. Dairy Sci. 55:1683-1691.

Egger, M., G. Davey Smith, M. Schneider, and C. Minder. 1997. Bias in meta-analysis detected by a simple graphical test. BMJ 315:629-634.

Ferguson, C. J. 2007. Evidence of publication bias in video game violence literature: A meta-analytic review. Aggress. Violent Behav. 12:470-482.

Funk, D. A., A. E. Freeman, and P. J. Berger. 1982. Environmental and physiological factors affecting mastitis at drying off and postcalving. J. Dairy Sci. 65:1258-1268.

Godden, S., P. Rapnicki, S. Stewart, J. Fetrow, A. Johnson, R. Bey, and R. Farnsworth. 2003. Effectiveness of an internal teat seal in the prevention of new intramammary infections during the dry and early-lactation periods in dairy cows when used with a dry cow intramammary antibiotic. J. Dairy Sci. 86:3899-3911.

Gregoire, G., F. Derderian, and J. LeLorier. 1995. Selecting the language of the publications included in a meta-analysis: Is there a tower of Babel bias? J. Clin. Epidemiol. 48:159-163.

Halasa, T., M. Nielen, T. Van Werven, H. Hogeveen, and O. Østerås. 2009. Meta-analysis of dry cow management for dairy cattle. Part 2. Cure of existing intramammary infections. J. Dairy Sci. 92:3150-3157.

Harmon, R. J., W. L. Crist, R. W. Hemken, and B. E. Langlois. 1986. Prevalence of minor udder pathogens after intramammary dry treatment. J. Dairy Sci. 69:843-849. 
Hassan, Z., R. C. W. Daniel, D. O'Boyle, and A. J. Frost. 1999. Effects of dry cow intramammary therapy on quarter infections in the dry period. Vet. Rec. 145:635-639.

Heald, C. W., G. M. Jones, S. Nickerson, and T. L. Bibb. 1977. Mastitis control by penicillin and novobiocin at drying-off. Can. Vet. J. 18:171-180.

Hogan, J. S., R. N. Gonzales, R. J. Harmon, S. C. Nickerson, S. P. Oliver, J. W. Pankey, and K. L. Smith. 1999. Laboratory Handbook on Bovine Mastitis. NMC, Verona, WI.

Hogan, J. S., K. L. Smith, D. A. Todhunter, and P. S. Schoenberger. 1994. Efficacy of dry cow therapy and a Propionibacterum acnes product in herds with low somatic cell count. J. Dairy Sci. 77:3331-3337.

Langley, O. H., J. Meaney, N. P. Cullen, and F. Cunningham. 1971. The control of mastitis. Vet. Rec. 89:315-316.

Meaney, W. J. 1976. Dry period teat seal. Vet. Rec. 99:30.

Meaney, W. J., and J. M. Mash. 1977. Comparison of two dry cow intramammary treatments. Vet. Rec. 100:492-493.

Morris, R. S., D. C. Blood, N. B. Williamson, C. M. Cannon, and R. M. Cannon. 1978. A healthy program for commercial dairy herds. 4. Changes in mastitis prevalence. Aust. Vet. J. 54:247-251.

Natzke, R. P., R. W. Everett, and D. R. Bray. 1975. Effect of drying off practices on mastitis infection. J. Dairy Sci. 58:1828-1835.

Orwin, R. 1983. A fail-safe $\mathrm{N}$ for effect size in meta-analysis. J. Educ. Stat. 8:157-159.

Østerås, O., J. Aursjø, G. G. Gjul, and A. Jørstad. 1994. Effect of drycow therapy on subclinical mastitis - An evaluation of long-acting and short-acting intramammaria. J. Vet. Med. B 41:529-540.

Pankey, J. W., R. M. Barker, A. Twomey, and G. Duirs. 1982a. A note on effectiveness of dry cow therapy in New Zealand dairy herds. N. Z. Vet. J. 30:50-52

Pankey, J. W., R. M. Barker, A. Twomey, and G. Duirs. 1982b. Comparative efficacy of dry-cow treatment regimens against Staphylococcus aureus. N. Z. Vet. J. 30:13-15.

Parkinson, T. J., J. J. Vermunt, and M. Merrall. 2000. Comparative efficacy of three dry cow antibiotic formulations in spring calving New Zealand dairy cows. N. Z. Vet. J. 48:129-135.

Pearson, J. K. L., and C. L. Wright. 1969. Dry cow therapy as a means of controlling bovine mastitis. Vet. Rec. 84:294-298.

Peters, J. L., A. J. Sutton, E. R. Jones, K. R. Abrams, and L. Rushton. 2006. Comparison of two methods to detect publication bias in meta-analysis. JAMA 295:676-680.
Postle, D. S., and R. P. Natzke. 1974. Efficacy of antibiotic treatment in the bovine udder as determined from field studies. Vet. Med. Small Anim. Clin. 69:1535-1539.

Rindsig, R. B., R. G. Rodewald, A. R. Smith, and S. L. Spahr. 1978. Complete versus selective dry cow therapy for mastitis control. J. Dairy Sci. 61:1483-1497.

Robert, A., H. Seegers, and N. Bareille. 2006. Incidence of intramammary infections during the dry period without or with antibiotic treatment in dairy cows-A quantitative analysis of published data. Vet. Res. 37:25-48.

Robinson, T. C., E. R. Jackson, and A. Marr. 1988. Mastitis incidence in quarters with different infection status at drying off and calving in two treatment groups. Br. Vet. J. 144:166-173.

Rothstein, H. 2008. Publication bias as a threat to the validity of meta-analytic results. J. Exp. Criminol. 4:61-81.

Rothstein, H., A. J. Sutton, and M. Borenstein. 2005. Publication bias in meta-analysis: Prevention, assessment and adjustments, John Wiley and Sons, Ltd, London, UK.

Schukken, Y. H., J. van Vliet, D. van de Geer, and F. J. Grommer. 1993. A randomized blind trial on dry cow antibiotic infusion in a low somatic cell count herd. J. Dairy Sci. 76:2925-2930.

Smith, A., D. R. Westgarth, M. R. Jones, F. K. Neave, F. H. Dodd, and G. C. Brander. 1967. Methods of reducing the incidence of udder infection in dry cows. Vet. Rec. 81:504-510.

Soback, S., G. Ziv, M. Winkler, and A. Saran. 1990. Systemic dry cow therapy-A preliminary report. J. Dairy Sci. 73:661-666.

Swenson, G. H. 1979. Posology and field efficacy study with novobiocin for intramammary infusion in nonlactating dairy cows. Can. J. Comp. Med. 43:440-447.

Tarabla, H., and V. Canavesio. 2003. Prevalence of intramammary infections by major pathogens at parturition in dairy cows after intramuscular antibiotic therapy at drying-off: A preliminary report. J. Dairy Res. 70:233-235.

Thornton, A., and P. Lee. 2000. Publication bias in meta-analysis: It causes and consequences. J. Clin. Epidemiol. 53:207-216.

Williamson, J. H., M. W. Woolford, and A. M. Day. 1995. The prophylactic effect of a dry-cow antibiotic against Streptococcus uberis. N. Z. Vet. J. 43:228-234.

Ziv, G., M. Storper, and A. Saran. 1981. Comparative efficacy of three antibiotic products for the treatment and prevention of subclinical mastitis during the dry period. Vet. Q. 3:74-79. 
Table A1. Description of the inclusion criteria and the IMI pathogens diagnosed per study

\begin{tabular}{|c|c|c|c|c|c|c|c|c|c|c|}
\hline Study & Inclusion criteria & \multicolumn{9}{|c|}{ Pathogen $^{1}$} \\
\hline Berry and Hillerton (2002a) & No or only Coryn..$^{2}$ IMI & & $\mathrm{X}$ & & & & $\mathrm{X}$ & $\mathrm{X}$ & $\mathrm{X}$ & $\mathrm{X}$ \\
\hline Berry and Hillerton (2007) & No major IMI pathogens & & & $\mathrm{X}$ & & & $\mathrm{X}$ & $\mathrm{X}$ & $\mathrm{X}$ & $\mathrm{X}$ \\
\hline Browning et al. (1994) & Medium SCC herds & & $\mathrm{X}$ & & & & $\mathrm{X}$ & & & $\mathrm{X}$ \\
\hline Bratlie $(1973)^{3}$ & IMI status & & & & & & & & & \\
\hline Eberhart and Buckalew (1972) & Not available & & $\mathrm{X}$ & & $\mathrm{X}$ & $\mathrm{X}$ & & & $\mathrm{X}$ & \\
\hline Funk et al. (1982) & Not available & $\mathrm{X}$ & & & $\mathrm{X}$ & $\mathrm{X}$ & & & & $\mathrm{X}$ \\
\hline Godden et al. (2003) & No clinical IMI & & $\mathrm{X}$ & $\mathrm{X}$ & & $\mathrm{X}$ & $\mathrm{X}$ & $\mathrm{X}$ & $\mathrm{X}$ & \\
\hline Harmon et al. (1986) & Not available & & $\mathrm{X}$ & $\mathrm{X}$ & $\mathrm{X}$ & & & & & $\mathrm{X}$ \\
\hline Hassan et al. (1999) & Not available & & $\mathrm{X}$ & & & $\mathrm{X}$ & $\mathrm{X}$ & $\mathrm{X}$ & $\mathrm{X}$ & $\mathrm{X}$ \\
\hline Heald et al. (1977) & Not available & & $\mathrm{X}$ & & $\mathrm{X}$ & $\mathrm{X}$ & & & $\mathrm{X}$ & $\mathrm{X}$ \\
\hline Østerås et al. (1994) & Cows with IMI & & $\mathrm{X}$ & $\mathrm{X}$ & & $\mathrm{X}$ & $\mathrm{X}$ & $\mathrm{X}$ & $\mathrm{X}$ & $\mathrm{X}$ \\
\hline Pankey et al. (1982a) & Not available & & $\mathrm{X}$ & & $\mathrm{X}$ & & $\mathrm{X}$ & & & \\
\hline Pankey et al. (1982b) & Had clinical IMI & & $\mathrm{X}$ & & & $\mathrm{X}$ & $\mathrm{X}$ & & & \\
\hline Pearson and Wright (1969) & Not available & & $\mathrm{X}$ & & $\mathrm{X}$ & & & & & $\mathrm{X}$ \\
\hline Postle and Natzke (1974) & Not available & & $\mathrm{X}$ & & $\mathrm{X}$ & $\mathrm{X}$ & & & & $\mathrm{X}$ \\
\hline Rindsig et al. (1978) & Not available & & $\mathrm{X}$ & & $\mathrm{X}$ & $\mathrm{X}$ & & & $\mathrm{X}$ & \\
\hline Robinson et al. (1988) & Low IMI rate herds & & $\mathrm{X}$ & & & & $\mathrm{X}$ & & $\mathrm{X}$ & $\mathrm{X}$ \\
\hline Schukken et al. (1993) & All dry-off cows & & $\mathrm{X}$ & $\mathrm{X}$ & & & & & & $\mathrm{X}$ \\
\hline Smith et al. (1967) & Not available & & $\mathrm{X}$ & & $\mathrm{X}$ & & & & & \\
\hline Soback et al. (1990) & Cows with SA IMI & & $\mathrm{X}$ & & & & & & & \\
\hline Swenson (1979) & Major IMI pathogens & & $\mathrm{X}$ & & $\mathrm{X}$ & $\mathrm{X}$ & & & & \\
\hline Tarabla and Canavesio (2003) & No major IMI pathogen & & $\mathrm{X}$ & & & & $\mathrm{X}$ & $\mathrm{X}$ & & \\
\hline Williamson et al. (1995) & Multiparous cows & & $\mathrm{X}$ & & & & $\mathrm{X}$ & & & $\mathrm{X}$ \\
\hline Ziv et al. (1981) & SCC level & & $\mathrm{X}$ & & $\mathrm{X}$ & & & & & \\
\hline
\end{tabular}

${ }^{1}$ IMI pathogens involved: Staphylococcus spp. (S), Staphylococcus aureus (SA), coagulase-negative staphylococci (CN), Streptococcus spp. (ST), Streptococcus agalactiae (Sag), Streptococcus uberis (SU), Streptococcus dysgalactiae (SD), coliforms (C), and other pathogens (O), which were mainly minor pathogens.

${ }^{2}$ Corynebacterium spp.

${ }^{3}$ No information was available about the isolated IMI pathogens. 
Table A2. The active ingredient per intervention ${ }^{1}$ per study and the control group type included in the meta-analysis sorted by intervention and alphabetical order ${ }^{2}$

\begin{tabular}{|c|c|c|}
\hline Intervention $^{1}$ and active ingredient & Control $^{3}$ & Study \\
\hline \multicolumn{3}{|l|}{ BDCT vs. no DCT } \\
\hline CP (Clox, $500 \mathrm{mg})$ & $\mathrm{NC}$ & $\begin{array}{l}\text { Cummins and McCaskey (1987) I; Postle and Natzke } \\
\text { (1974); Langley et al. (1971); Hassan et al. (1999) }\end{array}$ \\
\hline CP (Clox, $1.5 \mathrm{~g})$ & $\mathrm{NC}$ & Cummins and McCaskey (1987) II \\
\hline $\mathrm{CP}($ Tilco, $1.5 \mathrm{~g})$ & $\mathrm{NC}$ & Dingwell et al. (2002) \\
\hline $\mathrm{CP}\left(\mathrm{PP}, 0.2^{\mathrm{m}} \mathrm{IU}\right)+(\mathrm{DHS}, 100 \mathrm{mg})$ & $\mathrm{NC}$ & Eberhart and Buckalew (1972) \\
\hline $\begin{array}{l}\mathrm{EP} \mathrm{I}-\left(\mathrm{PP}, 1^{\mathrm{m}} \mathrm{IU}\right)+(\mathrm{DHS}, 1 \mathrm{~g}) / \mathrm{II}-(\mathrm{Clox}, 500 \mathrm{mg}) / \mathrm{III}-(\mathrm{Nov}, 50,200,400,600 \mathrm{mg}) / \mathrm{IV} \\
\left.\text { and V-(PP, 0.1, 0.2,0.4, } 1^{\mathrm{m}} \mathrm{IU}\right)+(\text { Nov, } 200,400 \mathrm{mg})\end{array}$ & $\mathrm{NC}$ & Funk et al. $(1982)^{4}$ \\
\hline CP I-(Nov, $400 \mathrm{mg}) / \mathrm{II}-(\mathrm{Cep}, 300 \mathrm{mg}) / \mathrm{III}-\left(\mathrm{PP}, 1^{\mathrm{m}} \mathrm{IU}\right)+(\mathrm{DHS}, 1 \mathrm{~g})$ & $\mathrm{NC}$ & Harmon et al. (1986) \\
\hline EP I-(PP, 0.1, 0.2, 0.4 $\left.{ }^{\mathrm{m}} \mathrm{IU}\right) / \mathrm{II}-(\mathrm{Nov}, 400,600 \mathrm{mg}) / \mathrm{III}-\left(\mathrm{PP}, 0.1,0.2,0.4^{\mathrm{m}} \mathrm{IU}\right)+(\mathrm{Nov}, 400 \mathrm{mg})$ & $\mathrm{NC}$ & Heald et al. (1977) \\
\hline CP I-(Cep, $300 \mathrm{mg})$ & $\mathrm{NC}$ & Hogan et al. (1994) \\
\hline $\mathrm{CP}(\mathrm{NA}, \mathrm{NA})$ & $\mathrm{NC}$ & Natzke et al. (1975) \\
\hline CP I- (Nov, $550 \mathrm{mg})+\left(\mathrm{PP}, 0.3^{\mathrm{m}} \mathrm{IU}\right) / \mathrm{II}-(\mathrm{Nov}, 400 \mathrm{mg})+\left(\mathrm{PP}, 0.2^{\mathrm{m}} \mathrm{IU}\right)$ & $\mathrm{NC}$ & Pankey et al. (1982a) \\
\hline CP DCT I-(Neo, $500 \mathrm{mg})+\left(\mathrm{PP}, 0.325^{\mathrm{m}} \mathrm{IU}\right) / \mathrm{CP}$ II-(Clox, $\left.500 \mathrm{mg}\right)$ & $\mathrm{NC}$ & Pankey et al. (1982b) \\
\hline CP I-(PP, $\left.0.35^{\mathrm{m}} \mathrm{IU}\right) / \mathrm{II}-(\mathrm{Clox}, 500 \mathrm{mg})$ & $\mathrm{NC}$ & Pearson and Wright (1969) \\
\hline $\mathrm{CP}\left(\mathrm{PP}, 0.3^{\mathrm{m}} \mathrm{IU}\right)+(\mathrm{DHS}, 100 \mathrm{mg})$ & $\mathrm{NC}$ & Schukken et al. (1993) \\
\hline CP I-(Clox, $0.2 \mathrm{~g}) / \mathrm{EP}$ II-(Clox, $0.1 \mathrm{~g})$ & $\mathrm{NC}$ & Smith et al. (1967) \\
\hline CP I-(Nor, $250 \mathrm{mg}$ )/II-(Oxy, $10 \mathrm{mg} / \mathrm{kg}) / \mathrm{III}-(\mathrm{Cep}, 500 \mathrm{mg})$ & $\mathrm{NC}$ & Soback et al. (1990) \\
\hline EP I-(Nov, $50 \mathrm{mg}) / \mathrm{II}-(\mathrm{Nov}, 200 \mathrm{mg}) / \mathrm{III}-(\mathrm{Nov}, 400 \mathrm{mg}) / \mathrm{IV}-(\mathrm{Nov}, 600 \mathrm{mg})$ & $\mathrm{NC}$ & Swenson (1979) \\
\hline $\mathrm{NA}(\mathrm{Spi}, 2.5 \mathrm{~g})+($ Str, $5 \mathrm{~g})$ & $\mathrm{NC}$ & Tarabla and Canavesio (2003) \\
\hline $\mathrm{CP}$ (Cephl, $250 \mathrm{mg})$ & $\mathrm{NC}$ & Williamson et al. (1995) \\
\hline \multicolumn{3}{|l|}{ Cloxacillin vs. other DCT products } \\
\hline $\mathrm{CP}\left(\mathrm{PP}, 0.2^{\mathrm{m}} \mathrm{IU}\right)+($ Novo, $400 \mathrm{mg})$ or $\mathrm{CP}(\mathrm{Clox}, 500 \mathrm{mg})$ & DCT & Davidson et al. (1994) \\
\hline $\mathrm{CP} \mathrm{I}-\left(\mathrm{PP}, 0.3^{\mathrm{m}} \mathrm{IU}\right)+($ Novo, $250 \mathrm{mg}) / \mathrm{II}-\left(\mathrm{BP}, 3^{\mathrm{m}} \mathrm{IU}\right)+\left(\mathrm{DHS}, 0.25^{\mathrm{m}} \mathrm{IU}\right)$ or $\mathrm{CP}(\mathrm{Clox}, 500 \mathrm{mg})$ & DCT & Langley et al. (1971) \\
\hline $\mathrm{CP}$ (DHS, $500 \mathrm{mg}$ ) or CP (Clox, NA) & DCT & Meaney and Mash (1977) \\
\hline $\mathrm{CP}(\mathrm{PP}, 300 \mathrm{mg})+(\mathrm{DHS}, 100 \mathrm{mg}) / \mathrm{CP}(\mathrm{SN}, 100 \mathrm{mg})$ or $\mathrm{CP}(\mathrm{Clox}, 500 \mathrm{mg})$ & DCT & Ziv et al. (1981) \\
\hline \multicolumn{3}{|l|}{ SDCT vs. no SDCT or SDCT vs. BDCT } \\
\hline CP I-(Cephl, $250 \mathrm{mg}) / \mathrm{CP}$ II-(Clox, $600 \mathrm{mg})$ & $\mathrm{NC}$ & Berry and Hillerton (2002a) \\
\hline $\mathrm{CP}$ (Clox, $500 \mathrm{mg}$ ) & $\mathrm{PC}$ & Browning et al. (1994) \\
\hline $\mathrm{CP}(\mathrm{Clox}, 500 \mathrm{mg})$ & $\mathrm{NC} / \mathrm{PC}$ & Hassan et al. (1999) \\
\hline $\mathrm{CP}\left(\mathrm{PP}, 1^{\mathrm{m}} \mathrm{IU}\right)+(\mathrm{DHS}, 1 \mathrm{~g})$ & $\mathrm{PC}$ & Rindsig et al. (1978) \\
\hline $\mathrm{CP}$ (Cephl. $250 \mathrm{mg}$ ) & $\mathrm{NC} / \mathrm{PC}$ & Williamson et al. (1995) \\
\hline $\mathrm{CP}(\mathrm{PP}, 1 \mathrm{~g})+(\mathrm{DHS}, 0.5 \mathrm{~g}) / \mathrm{CP}(\mathrm{Clox}, 500)$ & $\mathrm{PC}$ & Robinson et al. (1988) \\
\hline $\mathrm{CP}(\mathrm{PP}, \mathrm{NA})+(\mathrm{Neo}, \mathrm{NA})$ or $(\mathrm{Neo}, \mathrm{NA})$ or $(\mathrm{Clox}, \mathrm{NA})$ & $\mathrm{NC}$ & Bratlie (1973) \\
\hline CP I-(BP, $\left.0.1^{\mathrm{m}} \mathrm{IU}\right)+\left(\mathrm{PP}, 0.3^{\mathrm{m}} \mathrm{IU}\right)+(\mathrm{Neo}, 100 \mathrm{mg}) / \mathrm{II}-\left(\mathrm{BP}, 0.3^{\mathrm{m}} \mathrm{IU}\right)+(\mathrm{DHS}, 300 \mathrm{mg})$ & $\mathrm{NC}$ & Østerås et al. (1994) \\
\hline \multicolumn{3}{|l|}{ TS vs. no TS or TS + DCT vs. DCT } \\
\hline CP-TS & $\mathrm{NC}$ & Berry and Hillerton (2002b); Meaney (1976) \\
\hline CP-TS + CP-DCT (Cephl, NA) & $\mathrm{PC}$ & Berry and Hillerton (2007) \\
\hline CP-TS + CP-DCT (Clox, $500 \mathrm{mg})$ & $\mathrm{PC}$ & Godden et al. (2003) \\
\hline
\end{tabular}

${ }^{1}$ Type of intervention and the active ingredient of each intervention applied: blanket dry cow therapy (BDCT), cloxacillin (Clox) vs. other dry cow therapy (DCT) products, selecD. tive DCT (SDCT), and teat sealant (TS), preceded by the origin of the preparation; commercial (CP) or experimental preparation (EP); information not available (NA); and the Roman numerals represent protocols within a study. Preparations were as follows: the dose is presented per million international units ( $\left.{ }^{\mathrm{m}} \mathrm{IU}\right)$; procaine penicillin (PP) or benzyl penicillin (BP), dihydrostreptomycin (DHS), novobiocin (Nov), cephapirin (Cep), norfloxacin (Nor), neomycin (Neo), spiramycin (Spi), streptomycin (Str), cephalonium (Cephl), $\lesssim \quad$ sodium nafcillin (SN), tilcomicin sulfate (Tilco), oxytetracycline (Oxy).

${ }^{2}$ When more than one study or protocol within a study applied the same intervention, they were grouped together.

Z ${ }^{3}$ Control group was either a negative control (NC: had no treatment or had a placebo) or a positive control (PC: had an application that was also applied to the treatment group).

$\checkmark \quad{ }^{4}$ This study was also used in comparing the effect of cloxacillin with the other preparations; cloxacillin was used as the treatment group and the other preparations as controls. 

$\stackrel{\text { Table A3. Incidence }}{1}(\%)$ of new quarter IMI in treated (T) and control (C) groups and (the number of healthy quarters at the start in each group) for studies involved in the

\begin{tabular}{|c|c|c|c|c|c|c|c|c|c|c|}
\hline \multirow[b]{2}{*}{ Study } & \multicolumn{2}{|c|}{ Overall } & \multicolumn{2}{|c|}{ Staphylococcus } & \multicolumn{2}{|c|}{ Streptococcus } & \multicolumn{2}{|c|}{ Coliform } & \multicolumn{2}{|c|}{ Other } \\
\hline & $\mathrm{T}$ & $\mathrm{C}$ & $\mathrm{T}$ & $\mathrm{C}$ & $\mathrm{T}$ & $\mathrm{C}$ & $\mathrm{T}$ & $\mathrm{C}$ & $\mathrm{T}$ & $\mathrm{C}$ \\
\hline \multicolumn{11}{|l|}{ BDCT vs. no DCT } \\
\hline Cummins and McCaskey (1987) & $22 *(67)$ & $42(69)$ & $1.5 \mathrm{CP}^{*}, 0 \mathrm{CN}^{*}$ & $10 \mathrm{CP}, 15 \mathrm{CN}$ & OST & $10 \mathrm{ST}$ & $0^{*}$ & 2.9 & $20^{*}$ & 4.3 \\
\hline Dingwell et al. (2002) & $14^{*}(499)$ & $19(439)$ & & & & & & & & \\
\hline Eberhart and Buckalew (1972) I & $27 *(79)$ & $37(107)$ & $1.2 \mathrm{SA}^{*}$ & 12SA & $2.5 \mathrm{Sag}, 8.9 \mathrm{ST}^{*}$ & 3.7Sag, $15 \mathrm{ST}$ & 13 & 11 & 2.5 & 0 \\
\hline Funk et al. $(1982) \mathrm{I}^{5}$ & $9(794)$ & $12(2.093)$ & 4.4SA & 3.6SA & $0.9 \mathrm{Sag}, 2.8 \mathrm{ST}$ & 1.9Sag, 5.5ST & 1.4 & 1 & & \\
\hline Funk et al. (1982) $\mathrm{II}^{\wedge}$ & $9(710)$ & $12(2,093)$ & $4.4 \mathrm{SA}$ & $3.6 \mathrm{SA}$ & $0.1 \mathrm{Sag}, 4.4 \mathrm{ST}$ & $1.9 \mathrm{Sag}, 5.5 \mathrm{ST}$ & 0.6 & 1 & & \\
\hline Funk et al. (1982) III^^ & $5(5.610)$ & $12(2,093)$ & 3.2SA & 3.6SA & $0.5 \mathrm{Sag}, 1 \mathrm{ST}$ & 1.9Sag, 5.5ST & 1 & 1 & & \\
\hline Funk et al. $(1982) \mathrm{IV}^{\wedge}$ & $9(2.614)$ & $12(2.093)$ & 4.7SA & 3.6SA & 0Sag, 3.5ST & 1.9Sag, 5.5ST & 0.8 & 1 & & \\
\hline Funk et al. $(1982) \mathrm{V}^{\wedge}$ & $10(938)$ & $12(2,093)$ & $2.1 \mathrm{SA}$ & $3.6 \mathrm{SA}$ & 5.3Sag, $7.5 \mathrm{ST}$ & $1.9 \mathrm{Sag}, 5.5 \mathrm{ST}$ & 0.6 & 1 & & \\
\hline Harmon et al. (1986) I & $15(101)$ & $23(88)$ & 0SA, $8.9 \mathrm{CN}$ & 1.1SA, $10 \mathrm{CN}$ & $4 \mathrm{ST}$ & $6.8 \mathrm{ST}$ & 2 & 1.1 & $0^{*}$ & 3.7 \\
\hline Harmon et al. (1986) II & $7^{*}(112)$ & $23(88)$ & $0 \mathrm{SA}, 1.8 \mathrm{CN}^{*}$ & $1.1 \mathrm{SA}, 10 \mathrm{CN}$ & $1.8 \mathrm{ST}$ & $6.8 \mathrm{ST}$ & 0 & 1.1 & 3.6 & 3.7 \\
\hline Harmon et al. (1986) III & $22(98)$ & $23(88)$ & $0 \mathrm{SA}, 17 \mathrm{CN}$ & 1.1SA, $10 \mathrm{CN}$ & 1ST & $6.8 \mathrm{ST}$ & 1 & 1.1 & 3.1 & 3.7 \\
\hline Hassan et al. (1999) I & $7^{*}(153)$ & $16(173)$ & OSA & OSA & 1Sag, 0SU, 2SD & $\begin{array}{l}\text { 0.6Sag, } \\
\text { 0SU, 0SD }\end{array}$ & 2.6 & 0.8 & $1.3^{*}$ & 15 \\
\hline Heald et al. (1977) I^-I & $12(358)$ & $19(81)$ & $3.1 \mathrm{SA}$ & $2.5 \mathrm{SA}$ & $0.6 \mathrm{Sag}, 1.1 \mathrm{ST}$ & $2.5 \mathrm{Sag}, 16 \mathrm{ST}$ & & & 7.8 & 0 \\
\hline Heald et al. (1977) I^-II & $12(186)$ & $19(81)$ & $3.2 \mathrm{SA}$ & $2.5 \mathrm{SA}$ & $0.5 \mathrm{Sag}, 1.6 \mathrm{ST}$ & 2.5Sag, 16ST & & & 7 & 0 \\
\hline Heald et al. (1977) I^-III & $22(230)$ & $19(81)$ & $4 \mathrm{SA}$ & $2.5 \mathrm{SA}$ & $0.6 \mathrm{Sag}, 2.1 \mathrm{ST}$ & 2.5Sag, $16 \mathrm{ST}$ & & & 15.6 & 0 \\
\hline Hogan et al. (1994) I & $26^{*}(274)$ & $33(291)$ & 1.5SA, $16.4 \mathrm{~S}$ & 2.7SA, $17.2 \mathrm{~S}$ & $2.6 \mathrm{ST}^{*}$ & 4.8ST & 0 & 0 & 7.3 & 11 \\
\hline Natzke et al. (1975) & $7^{*}(397)$ & $13(402)$ & & & & & & & & \\
\hline Pankey et al. (1982a) & $10^{*}(186)$ & $15(179)$ & $4.8 \mathrm{SA}^{*}$ & 10SA & $4.8 \mathrm{SU}$ & $5.1 \mathrm{SU}$ & & & & \\
\hline Pankey et al. (1982b) & $17(117)$ & $22(117)$ & 10SA & $12 \mathrm{SA}$ & 0Sag, 6.8SU & 3.4Sag, 6.8SU & & & & \\
\hline Pearson and Wright (1969) I & $14(73)$ & $16(296)$ & $11 \mathrm{CP}$ & $11.8 \mathrm{CP}$ & $1.4 \mathrm{ST}$ & $3 \mathrm{ST}$ & & & 1.4 & 1.4 \\
\hline Pearson and Wright (1969) II & $12(108)$ & $12(106)$ & $7.4 \mathrm{CP}$ & $5.7 \mathrm{CP}$ & $2.8 \mathrm{ST}$ & 4.7ST & & & 1.9 & 1.9 \\
\hline Schukken et al. (1993) & $37(16)$ & $50(16)$ & OSA, $6.3 \mathrm{CN}$ & $0 \mathrm{SA}, 6.3 \mathrm{CN}$ & & & & & 31.2 & 44 \\
\hline Postle and Natzke (1974) & $9(1,423)$ & $16(589)$ & $1.7 \mathrm{SA}$ & $2.2 \mathrm{SA}$ & $0.8 \mathrm{Sag}, 4.9 \mathrm{ST}$ & $3.7 \mathrm{Sag}, 10.2 \mathrm{ST}$ & 1.9 & 3.1 & & \\
\hline Smith et al. (1967) I & $2^{*}(532)$ & $16(420)$ & $0.8 \mathrm{SA}^{*}$ & 8.3SA & $1.5 \mathrm{ST}^{*}$ & $7.6 \mathrm{ST}$ & & & & \\
\hline Smith et al. (1967) II & $2^{*}(544)$ & $16(420)$ & $0.2 \mathrm{SA}^{*}$ & 8.3SA & $1.8 \mathrm{ST}^{*}$ & 7.6ST & & & & \\
\hline Soback et al. (1990) I & $(131)$ & $(65)$ & $18.3 \mathrm{CP}^{*}$ & $29.2 \mathrm{CP}$ & & & & & & \\
\hline Soback et al. (1990) II & $(62)$ & $(65)$ & $9.7 \mathrm{CP}^{*}$ & $29.2 \mathrm{CP}$ & & & & & & \\
\hline Soback et al. (1990) III & $(58)$ & (65) & $51.7 \mathrm{CP}^{*}$ & $29.2 \mathrm{CP}$ & & & & & & \\
\hline Swenson (1979) I & $10(1,025)$ & $10(1,017)$ & $4.4 \mathrm{SA}^{*}$ & $2.6 \mathrm{SA}$ & 1.7Sag, 5.1ST* & 2.1Sag, 7.6ST & & & & \\
\hline Swenson (1979) II & $6^{*}(1,049)$ & $10(1,017)$ & $3.2 \mathrm{SA}$ & $2.6 \mathrm{SA}$ & $0.6 \mathrm{Sag}^{*}, 2.3 \mathrm{ST}^{*}$ & 2.1Sag, 7.6ST & & & & \\
\hline Swenson (1979) III & $7^{*}(1.049)$ & $10(1.017)$ & $2.9 \mathrm{SA}$ & $2.6 \mathrm{SA}$ & $0.4 \mathrm{Sag}^{*}$ 3.7ST & 2.1Sag, 7.6ST & & & & \\
\hline Swenson (1979) IV & $6^{*}(1,057)$ & $10(1,017)$ & $2.7 \mathrm{SA}$ & $2.6 \mathrm{SA}$ & 0.4 Sag*, 2.9 ST* $^{*}$ & 2.1Sag, $7.6 \mathrm{ST}$ & & & & \\
\hline Tarabla and Canavesio (2003) & $2^{*}(88)$ & $11(88)$ & $0 \mathrm{SA}$ & $2.3 \mathrm{SA}$ & $2.3 \mathrm{SD}, \mathrm{SSU}^{*}$ & $1.1 \mathrm{SD}, 8 \mathrm{SU}$ & & & & \\
\hline Langley et al. (1971) & $(160)$ & $(154)$ & $2.5 \mathrm{SA}$ & $4.6 \mathrm{SA}$ & & & & & & \\
\hline Williamson et al. (1995) I & $4^{*}(556)$ & $10(516)$ & $0.7 \mathrm{SA}$ & $0.8 \mathrm{SA}$ & $0.4 \mathrm{SU}^{*}$ & $6.4 \mathrm{SU}$ & & & 3.2 & 3.1 \\
\hline \multicolumn{11}{|l|}{ Cloxacillin vs. other DCT products } \\
\hline Davidson et al. (1994) & & & $3.1 \mathrm{CN}(160)$ & $5.5 \mathrm{CN}(164)$ & & & & & & \\
\hline Langley et al. (1971) I & $(744)$ & $(690)$ & $1.7 \mathrm{SA}$ & $1.7 \mathrm{SA}$ & & & & & & \\
\hline Langley et al. (1971) II & $(744)$ & $(703)$ & $1.7 * \mathrm{SA}$ & 3SA & & & & & & \\
\hline Meaney and Mash (1977) & $1^{*}(277)$ & $3(280)$ & & & & & & & & \\
\hline Ziv et al. (1981) I & $45(135)$ & $40(455)$ & $27 \mathrm{SA}$ & $20.7 \mathrm{SA}$ & $18.2 \mathrm{ST}$ & 19.6ST & & & & \\
\hline
\end{tabular}


Table A3 (Continued). Incidence ${ }^{1}(\%)$ of new quarter IMI in treated (T) and control (C) groups and (the number of healthy quarters at the start in each group) for studies involved in the meta-analyses per intervention and pathogen group ${ }^{2,3}$

\begin{tabular}{|c|c|c|c|c|c|c|c|c|c|c|}
\hline \multirow[b]{2}{*}{ Study } & \multicolumn{2}{|c|}{ Overall } & \multicolumn{2}{|c|}{ Staphylococcus } & \multicolumn{2}{|c|}{ Streptococcus } & \multicolumn{2}{|c|}{ Coliform } & \multicolumn{2}{|c|}{ Other } \\
\hline & $\mathrm{T}$ & $\mathrm{C}$ & $\mathrm{T}$ & $\mathrm{C}$ & $\mathrm{T}$ & $\mathrm{C}$ & $\mathrm{T}$ & $\mathrm{C}$ & $\mathrm{T}$ & $\mathrm{C}$ \\
\hline \multicolumn{11}{|c|}{ SDCT vs. no DCT or SDCT vs. BDCT } \\
\hline Berry and Hillerton (2002a) I & $4^{*}(318)$ & $7(341)$ & OSA & $1.5 \mathrm{SA}$ & $1.3 \mathrm{SU}^{*}$ & $4.1 \mathrm{SU}$ & 2.5 & 1.5 & & \\
\hline Berry and Hillerton (2002a) II & $0 *(54)$ & $17(58)$ & $0 \mathrm{SA}^{*}$ & $10.4 \mathrm{SA}$ & OSU* & $6.9 \mathrm{SU}$ & 0 & 0 & & \\
\hline Bratlie (1973) & $10(313)$ & $12(143)$ & & & & & & & & \\
\hline Browning et al. (1994) I & $6(1,822)$ & $2(1,805)$ & & & & & & & & \\
\hline Browning et al. (1994) II & $4(1,837)$ & $3(1,805)$ & & & & & & & & \\
\hline Hassan et al. (1999) II & $2(126)$ & $18(173)$ & OSA & $0.8 \mathrm{SA}$ & $\begin{array}{l}\text { 0Sag, } 0.8 \mathrm{SU} \\
\text { 0.8SD }\end{array}$ & $\begin{array}{l}\text { 0Sag, 0SU, } \\
3.2 \mathrm{SD}\end{array}$ & 0.8 & 0.8 & 0 & 13.4 \\
\hline Hassan et al. (1999) III & $2(126)$ & $7(153)$ & OSA & $0.8 \mathrm{SA}$ & $\begin{array}{l}\text { 0Sag, 0.8SU, } \\
\text { 0.8SD }\end{array}$ & $\begin{array}{l}1 \mathrm{Sag}, 0 \mathrm{SU}, \\
2 \mathrm{SD}\end{array}$ & 0.8 & 2.6 & 0 & 1.3 \\
\hline Østerås et al. (1994) I & $16^{*}(297)$ & $24(275)$ & & & & & & & & \\
\hline Østerås et al. (1994) II & $19(259)$ & $24(275)$ & & & & & & & & \\
\hline Rindsig et al. (1978) II & $7(216)$ & $8(181)$ & $4.2 \mathrm{SA}$ & $6 \mathrm{SA}$ & 0.9Sag, $1.8 \mathrm{ST}$ & 0.6Sag, 0ST & 0 & 1.1 & 0.9 & 0 \\
\hline Robinson et al. (1988) & $15(986)$ & $7(1,424)$ & & & & & & & & \\
\hline Williamson et al. (1995) II & $2(120)$ & $10(516)$ & & & & & & & & \\
\hline Williamson et al. (1995) III & $11(141)$ & $10(516)$ & & & & & & & & \\
\hline \multicolumn{11}{|c|}{ TS vs. no TS and TS + DCT vs. DCT } \\
\hline Berry and Hillerton (2002b) & $2^{*}(704)$ & $7(556)$ & $1 \mathrm{SA}^{*}$ & $2.5 \mathrm{SA}$ & $1 \mathrm{SU}^{*}$ & $3.4 \mathrm{SU}$ & 0 & 0.8 & & \\
\hline Berry and Hillerton (2007) & $4^{*}(574)$ & $8(492)$ & $1.7 \mathrm{CN}$ & $2.6 \mathrm{CN}$ & 1.4SU, 0SD & $3.5 \mathrm{SU}, 0.2 \mathrm{SD}$ & 0.3 & 1 & 0.3 & 0.6 \\
\hline Godden et al. (2003) & $29 *(575)$ & $37(552)$ & $1.2 \mathrm{SA}, 9.2 \mathrm{CN}$ & $1.8 \mathrm{SA}, 12 \mathrm{CN}$ & $\begin{array}{l}\text { 0Sag, 6.1SU, } \\
0.3 \mathrm{SD}\end{array}$ & $\begin{array}{l}0.4 \mathrm{Sag}, 3.3 \mathrm{SU} \text {, } \\
1.5 \mathrm{SD}\end{array}$ & 11.5 & 12.3 & 0.9 & 5.4 \\
\hline Meaney (1976) & $4^{*}(28)$ & $32(28)$ & & & & & & & & \\
\hline
\end{tabular}

${ }^{1}$ The number of new IMI quarters during the dry period up to $21 \mathrm{~d}$ postcalving divided by the number of healthy quarters at dry off. The incidence is presented as a percentage.

2Interventions were as follows: blanket dry cow therapy (BDCT), cloxacillin vs, other dry cow therapy (DCT) products, selective dry cow therapy (SDCT), teat sealant (TS), external nonantibiotic formulation for the immune system (IS), and teat dipping (TD). Pathogens are as follows: all diagnosed Staphylococcus spp. (S), Staphylococcus aureus (SA), coagulase-positive Staphylococcus spp. (CP), coagulase-negative Staphylococcus spp. (CN), all diagnosed Streptococcus spp. (ST), Streptococcus uberis (SU), Streptococcus dysgalactiae (SD), and Streptococcus agalactiae (Sag).

${ }^{3}$ Use of symbols: an asterisk $(*)$ indicates significantly different from the comparative control group $(P<0.05)$; a circumflex $\left({ }^{\wedge}\right)$ indicates no statistical analysis was conducted; no script indicates statistical significance was not found or not mentioned in the original study.

${ }^{4}$ The Roman numerals represent protocols within a study.

${ }^{5}$ This study was also used for the comparison of cloxacillin vs. other DCT products, where the protocol of cloxacillin treatment (Funk et al., 1982) II was used as the treatment 